\title{
Kajian Pengaruh Dataset dan Bias Dataset terhadap Performa Akurasi Deteksi Objek
}

\author{
Ridho Imantiyar ${ }^{l}$; Dhomas Hatta Fudholi ${ }^{2}$ \\ 1,2 Jurusan Informatika, Fakultas Teknologi Industri, Universitas Islam Indonesia \\ ${ }^{1} 18523170 @$ students.uii.ac.id \\ ${ }^{2}$ hatta.fudholi@uii.ac.id
}

\begin{abstract}
Object detection is the ability of the system to recognize certain objects in an image or video. In the object detection process, the system can give inappropriate results or cannot detect the object caused by the non-optimal datasets. The purpose of the research is to study the process of creating datasets and the biases that arise. The literature search was carried out on Google Scholar, Science Direct, and DSpace Repository by entering the main keywords of "data centric", "object detection datasets", and "datasets bias". The results of literature analysis included datasets and its biases. In the previous study, there were shortcomings such as the absence of system performance improvement to detect objects through datasets optimization. The literature review indicated that the process of creating a proper dataset can be done by adjusting shooting conditions during data collection and field testing. In addition, improving the generalization ability of the system can be done by adding image variations to the dataset through augmentation technique. Furthermore, in the process of creating dataset, there will always be the presence of dataset bias, thus affecting the ability of object detection. Therefore, in the process of creating an object detection system, data has a considerable effect on the accuracy performance of the object detection.
\end{abstract}

Keywords: dataset, bias, accuracy, object detection

\begin{abstract}
ABSTRAK
Deteksi objek merupakan kemampuan sistem yang dapat mengenali objek tertentu yang berada dalam suatu gambar atau video. Dalam proses deteksi objek, sistem bisa memberikan hasil yang tidak sesuai atau tidak dapat mendeteksi suatu objek yang disebabkan oleh dataset yang tidak optimal. Penelitian ini bertujuan mengkaji proses pembuatan dataset dan bias yang muncul. Pencarian dan analisis dilakukan terhadap literatur yang berkaitan dengan dataset deteksi objek. Proses pencarian literatur dilakukan pada Google Scholar, Science Direct, dan DSpace Repository dengan memasukkan kata kunci utama "data centric", "object detection dataset", dan "dataset bias". Hasil analisis literatur meliputi dataset dan bias dataset. Pada penelitian sebelumnya terdapat kekurangan seperti belum adanya peningkatan performa sistem deteksi objek melalui pengoptimalan dataset. Dari kajian literatur, pembuatan dataset yang baik dapat dilakukan dengan cara menyesuaikan kondisi pengambilan gambar saat pengumpulan data dan pengujian di lapangan. Selain itu, untuk dapat menambah kemampuan generalisasi sistem dengan cara menambahkan variasi gambar dalam dataset melalui teknik augmentasi. Selanjutnya, dalam proses pembuatan dataset pasti akan selalu ada bias dalam data sehingga mempengaruhi kemampuan deteksi objek. Oleh karena itu, dalam proses pembuatan sistem deteksi objek, data memiliki pengaruh yang cukup besar terhadap performa akurasi deteksi objek.
\end{abstract}

Kata kunci: dataset, bias, akurasi, deteksi objek 


\section{PENDAHULUAN}

Deteksi objek (Object detection) merupakan kemampuan sistem yang dapat mengenali suatu objek yang berada dalam suatu gambar atau video. Deteksi objek merupakan salah satu teknologi yang ada pada Computer Vision. Pada deteksi objek, sistem menerima masukan berupa gambar dan memberikan respon dengan cara menunjukkan hasil klasifikasi yang sesuai dengan gambar. Pada umumnya, deteksi objek digunakan untuk mengenali objek seperti manusia, bangunan, atau mobil. Seiring dengan perkembangan teknologi, deteksi objek memiliki banyak penerapan di bidang visi komputer, termasuk dalam peningkatan automasi. [1]

Secara umum, permasalahan terkait deteksi objek dapat diselesaikan dengan menggunakan metode-metode komputasi berbasis pembelajaran mesin (Machine Learning) atau komputasi berbasis pembelajaran dalam (Deep Learning). Perbedaan kedua metode tersebut terletak pada pembelajaran yang dilakukan, pada Deep Learning pembelajaran dilakukan dengan lebih mendalam dan kompleks. Salah satu metode yang dapat diterapkan dalam deteksi objek, yakni menggunakan TensorFlow Object Detection API. Metode tersebut berbasis pembelajaran dalam dan menyediakan berbagai macam model pra-latih. Dalam metode tersebut, model yang umum digunakan adalah $S S D$ Mobilenet V2. Model tersebut dapat melakukan deteksi objek dengan akurasi yang cukup baik pada setiap objek yang ada di suatu gambar. [2].

Selain penggunaan teknik komputasi, metode, dan model yang tepat, perlu juga melakukan pengumpulan data. Tanpa adanya data maka sistem tidak dapat dilatih serta tidak dapat mengenali objek. Dalam deteksi objek, data yang digunakan untuk melatih suatu model berupa kumpulan gambar. Gambar tersebut berjumlah puluhan, ratusan, hingga beribu-ribu banyaknya. Di dalam gambar tersebut terdapat objek yang akan diberikan label. Pemberian label tersebut bertujuan agar sistem dapat mempelajari objek. Setelah melakukan pengumpulan data, pemrosesan data, dan pelatihan data maka sistem dapat mengenali objek yang ada pada masukan gambar. Data yang cukup terkenal dan sering digunakan oleh peneliti untuk melakukan pengujian terhadap suatu model adalah data yang bersumber dari PASCAL VOC dan COCO. Kedua sumber data tersebut memiliki parameter uji yang baik. [3].

Kemajuan teknologi pada deteksi objek telah membentuk kumpulan data yang besar dan memiliki skala yang besar. Sebagian data tersebut telah tersebar di internet dan dapat digunakan untuk keperluan pengembangan sistem. Hal penting terkait data, yakni data dapat mempengaruhi akurasi deteksi objek. Meskipun data yang telah dikumpulkan banyak dan sudah merepresentasikan suatu objek, hal tersebut tidak dapat menjamin akurasi yang dihasilkan oleh sistem deteksi objek akan baik juga. Dalam kumpulan data yang banyak pasti terdapat data yang bias di dalamnya. Selain itu, pasti akan ada kesalahan kecil yang ditimbulkan oleh manusia sehingga menambah bias dalam data. [4].

\section{METODE}

Pada bagian ini akan dijelaskan mengenai metode yang digunakan dalam pencarian literatur serta metode analisis yang dilakukan pada literatur terpilih.

\subsection{Metode Pencarian}

Pengumpulan literatur didapatkan dari Google Scholar, Science Direct, dan DSpace Repository dengan menggunakan kata kunci utama berupa, data centric, object detection dataset, dan dataset bias. Pengumpulan literatur dilakukan dengan cara memilih publikasi ilmiah yang sesuai dengan kasus deteksi objek. Selain itu, pengumpulan juga dilakukan dengan cara menelusuri daftar 
pustaka yang sesuai dari literatur yang dikaji. Setelah proses pengumpulan, dilakukan proses pemilihan literatur berdasarkan kriteria berikut:

a. Literatur yang dipilih merupakan publikasi ilmiah yang memiliki rentang tahun diantara 2017 dan 2021 yang mempunyai indikasi kebaruan.

b. Literatur membahas tentang pengaruh bias dataset.

c. Literatur membahas tentang deteksi objek.

d. Literatur membahas tentang proses pengumpulan dan pengolahan dataset.

\subsection{Metode Analisis}

Literatur yang terpilih pada proses pencarian kemudian akan dianalisis yang kemudian hasilnya dipaparkan dalam bentuk tabel. Proses analisis ini bertujuan untuk memperoleh informasiinformasi yang dapat digunakan untuk menemukan pengaruh dataset terhadap performa deteksi objek. Analisis yang dilakukan berfokus pada dua konteks utama, yakni dataset yang digunakan dan pengaruh bias dataset. Pada konteks dataset yang digunakan, dilakukan perbandingan proses pengolahan data serta persiapannya yang berbeda-beda. Selain itu, analisis dari pengaruh dataset juga dilakukan dengan melihat data terkait, seperti jumlah kelas, jumlah gambar, algoritma, epoch, dan nilai mmAP. Pada konteks pengaruh bias dataset, dipaparkan jenis-jenis bias yang mempengaruhi performa deteksi objek.

\section{HASIL DAN PEMBAHASAN}

Hasil dari proses pencarian literatur ditemukan 46 makalah dengan kata kunci yang diberikan. Dari ke 46 makalah tersebut, didapatkan 16 makalah yang memenuhi kriteria pencarian. Makalahmakalah yang tidak memenuhi kriteria diantaranya, yakni 7 makalah tidak memenuhi rentang tahun penulisan antara 2017 hingga 2021, 10 makalah membahas proses peningkatan performa melalui algoritma, dan 13 makalah tidak lengkap pembahasannya mengenai peroses pengolahan dataset. Tabel 1 memberikan perbandingan langsung dari komponen data atau kriteria yang diperlukan pada masing-masing makalah, termasuk di dalamnya dataset, jumlah kelas, jumlah gambar, algortima, epoch, dan mAP.

Berdasarkan Tabel 1, diperoleh 26 macam dataset yang digunakan dalam pelatihan deteksi objek. Jumlah kelas dan gambar yang digunakan pun cukup beragam, mulai dari 2 kelas hingga 365 kelas dan 600 gambar hingga yang terbanyak 638000 gambar. Pada tabel tersebut dapat dilihat juga jumlah gambar yang banyak tidak selalu memberikan nilai mAP yang tinggi begitu juga sebaliknya. Setiap dataset yang ada pada Tabel 1 dipersiapkan untuk keperluan yang berbeda-beda sehingga selanjutnya akan dilakukan analisis dataset dan bias.

Tabel 1. Hasil Kajian Literatur

\begin{tabular}{|c|l|l|l|l|l|l|l|}
\hline Makalah & Dataset & $\begin{array}{l}\text { Jumlah } \\
\text { Kelas }\end{array}$ & $\begin{array}{c}\text { Jumlah } \\
\text { gambar }\end{array}$ & $\begin{array}{c}\text { Algorit } \\
\text { ma }\end{array}$ & Epoch & mAP & Hasil/Keluaran \\
\hline$[3]$ & $\begin{array}{l}\text { Objects } \\
365\end{array}$ & 365 & 638000 & $\begin{array}{l}\text { FPN dan } \\
\text { RetinaN } \\
\text { et }\end{array}$ & 90000 & 86.7 & $\begin{array}{l}\text { Menghasilkan performa } \\
\text { yang lebih baik } \\
\text { dibandingkan dengan dataset } \\
\text { PASCAL VOC dan COCO } \\
\text { dengan iterasi yang lebih } \\
\text { sedikit. }\end{array}$ \\
\hline
\end{tabular}


PETIR: Jurnal Pengkajian dan Penerapan Teknik Informatika

Vol. 14, No. 2, September 2021, P-ISSN 1978-9262, E-ISSN 2655-5018

DOI: https://doi.org/10.33322/petir.v14i2.1150

\begin{tabular}{|c|c|c|c|c|c|c|c|}
\hline Makalah & Dataset & $\begin{array}{c}\text { Jumlah } \\
\text { Kelas }\end{array}$ & $\begin{array}{l}\text { Jumlah } \\
\text { gambar }\end{array}$ & $\begin{array}{c}\text { Algorit } \\
\text { ma }\end{array}$ & Epoch & $\mathbf{m A P}$ & Hasil/Keluaran \\
\hline [4] & $\begin{array}{l}\text { Visual } \\
\text { Dataset } \\
\text { (Caltec } \\
\text { h101, } \\
\text { LabelM } \\
\text { e, SUN, } \\
\text { PASCA } \\
\text { L) }\end{array}$ & 5 & N/A & $\begin{array}{l}\text { Max- } \\
\text { margin } \\
(\mathrm{SVM})\end{array}$ & N/A & 74.3 & $\begin{array}{l}\text { Mengembangkan model } \\
\text { yang dapat mengurangi bias } \\
\text { yang ada dalam dataset } \\
\text { sehingga performa menjadi } \\
\text { lebih baik. }\end{array}$ \\
\hline [5] & $\begin{array}{l}\text { ModaN } \\
\text { et }\end{array}$ & 13 & 55176 & $\begin{array}{l}\text { Faster } \\
\text { RCNN, } \\
\text { SSD, } \\
\text { and } \\
\text { YOLO }\end{array}$ & N/A & 90.0 & $\begin{array}{l}\text { Menciptakan dataset untuk } \\
\text { keperluan fashion dengan } \\
\text { akurasi objek yang cukup } \\
\text { baik dengan menerapkan } \\
\text { beberapa aturan dalam } \\
\text { anotasi dan pemilihan model } \\
\text { yang bagus. }\end{array}$ \\
\hline [6] & $\begin{array}{l}\text { Otomot } \\
\text { ive } \\
\text { Recordi } \\
\text { ng }\end{array}$ & 2 & 100800 & DPM & N/A & N/A & $\begin{array}{l}\text { Membuat dataset dari } \\
\text { kamera mobil dengan } \\
\text { berbagai macam kondisi } \\
\text { sesuai dengan hasil rekaman } \\
\text { kamera. }\end{array}$ \\
\hline [7] & $\begin{array}{l}\text { Dataset } \\
\text { for } \\
\text { Object } \\
\text { deTecti } \\
\text { on in } \\
\text { Aerial } \\
\text { images } \\
\text { (DOTA } \\
\text { ) }\end{array}$ & 15 & 2806 & $\begin{array}{l}\text { Faster } \\
\text { R- } \\
\text { CNN2, } \\
\text { R- } \\
\text { FCN3, } \\
\text { YOLOv } \\
24 \text { and } \\
\text { SSD }\end{array}$ & N/A & $\begin{array}{l}25.492 \\
30.84 \\
17.84 \\
39.95 \\
\text { dan } \\
54.13\end{array}$ & $\begin{array}{l}\text { Membuat dataset yang } \\
\text { bersumber dari permukaan } \\
\text { bumi, gambar berisikan } \\
\text { permukaan bumi, dataset } \\
\text { tersebut dapat membantu } \\
\text { sistem untuk mendeteksi } \\
\text { objek yang ada di } \\
\text { permukaan bumi }\end{array}$ \\
\hline [8] & $\begin{array}{l}\text { Oktober } \\
\text { fest }\end{array}$ & 15 & 1110 & $\begin{array}{l}\text { SSD, } \\
\text { RetinaN } \\
\text { et, } \\
\text { RFCN }\end{array}$ & N/A & 24.3 & $\begin{array}{l}\text { Mendeteksi makanan untuk } \\
\text { menentukan harganya } \\
\text { sehingga mempercepat } \\
\text { proses pembayaran. }\end{array}$ \\
\hline [9] & $\begin{array}{l}\text { Boat } \\
\text { Re-ID }\end{array}$ & 107 & 5523 & $\begin{array}{l}\text { ResNet5 } \\
0, \\
\text { VGG16 } \\
\text { and } \\
\text { DenseN } \\
\text { Et121 }\end{array}$ & 60 & $\begin{array}{l}86.78 \\
91.89 \\
\text { dan } \\
85.69\end{array}$ & $\begin{array}{l}\text { Menciptakan dataset untuk } \\
\text { dapat mendeteksi kapal } \\
\text { dengan akurasi yang cukup } \\
\text { tinggi. }\end{array}$ \\
\hline [10] & Iranis & 28 & 83844 & $\begin{array}{l}\text { YOLO } \\
\text { v.3 }\end{array}$ & N/A & $\begin{array}{l}97.480 \\
4\end{array}$ & $\begin{array}{l}\text { Mampu mendeteksi nomor } \\
\text { plat dengan angka iran } \\
\text { sehingga dapat membantu } \\
\text { ITS (Intelligent }\end{array}$ \\
\hline
\end{tabular}




\begin{tabular}{|c|c|c|c|c|c|c|c|}
\hline Makalah & Dataset & $\begin{array}{c}\text { Jumlah } \\
\text { Kelas }\end{array}$ & $\begin{array}{l}\text { Jumlah } \\
\text { gambar }\end{array}$ & $\begin{array}{c}\text { Algorit } \\
\text { ma }\end{array}$ & Epoch & $\mathbf{m A P}$ & Hasil/Keluaran \\
\hline & & & & & & & $\begin{array}{l}\text { Transportation Systems) } \\
\text { pada negara Iran. }\end{array}$ \\
\hline [11] & $\begin{array}{l}\text { Jalanan } \\
\text { rusak } \\
\text { yang } \\
\text { dikump } \\
\text { ulkan } \\
\text { dengan } \\
\text { smartph } \\
\text { one } \\
\end{array}$ & 8 & 163664 & $\begin{array}{l}\text { Faster- } \\
\text { RCNN, } \\
\text { YOLO, } \\
\text { R-FCN, } \\
\text { dan SSD }\end{array}$ & 10000 & 75.00 & $\begin{array}{l}\text { Pengumpulan data dengan } \\
\text { kamera smartphone dan } \\
\text { dapat mendeteksi jalan yang } \\
\text { rusak dengan baik. }\end{array}$ \\
\hline [12] & $\begin{array}{l}\text { Rambu } \\
\text { Kesehat } \\
\text { an dan } \\
\text { Kesela } \\
\text { matan } \\
\text { (K3) }\end{array}$ & 2 & 1500 & $\begin{array}{l}\text { pre- } \\
\text { trained } \\
\text { model } \\
\text { SSD- } \\
\text { mobilen } \\
\text { et V1 }\end{array}$ & 69.284 & $\begin{array}{l}50.0- \\
97.0\end{array}$ & $\begin{array}{l}\text { Implementasi deteksi objek } \\
\text { untuk dapat mendeteksi } \\
\text { rambu K3 dengan akurasi } \\
\text { berkisar antara 50\%-97\%. }\end{array}$ \\
\hline [13] & $\begin{array}{l}\text { Empat } \\
\text { macam } \\
\text { kendara } \\
\text { an }\end{array}$ & 4 & 200 & $\begin{array}{l}\text { Convolu } \\
\text { tional } \\
\text { Neural } \\
\text { Network } \\
(\mathrm{CNN}) \\
\end{array}$ & 10000 & 81.0 & $\begin{array}{l}\text { Menggolongkan empat jenis } \\
\text { kendaraan untuk mengurangi } \\
\text { kemacetan yang terjadi pada } \\
\text { jalan tol. }\end{array}$ \\
\hline [14] & $\begin{array}{l}\text { Pascal } \\
\text { VOC } \\
\text { dan } \\
\text { COCO }\end{array}$ & 100 & 45786 & $\begin{array}{l}\text { Tiny- } \\
\text { YOLOV } \\
2 \text { SSD } \\
\text { Mobilen } \\
\text { et V1 } \\
\text { YOLO- } \\
\text { LITE }\end{array}$ & N/A & $\begin{array}{l}23.7 \\
21.0 \\
\text { dan } \\
12.26\end{array}$ & $\begin{array}{l}\text { Mengembangkan model } \\
\text { deteksi yang dapat bekerja } \\
\text { pada perangkat yang } \\
\text { memiliki kemampuan } \\
\text { pengolahan grafis yang } \\
\text { rendah. }\end{array}$ \\
\hline [15] & $\begin{array}{l}\text { Kondisi } \\
\text { dalam } \\
\text { rumah }\end{array}$ & 20 & 28000 & $\begin{array}{l}\text { pretrain } \\
\text { ed } \\
\text { ResNet- } \\
18\end{array}$ & 25 & 69.9 & $\begin{array}{l}\text { Data yang dibuat di lab tidak } \\
\text { memiliki akurasi yang baik } \\
\text { dibanding dengan data yang } \\
\text { langsung diambil dari } \\
\text { rumah. Peningkatan akurasi } \\
\text { sebesar } 43.7 \% \text {. }\end{array}$ \\
\hline [16] & $\begin{array}{l}\text { Data } \\
\text { wajah } \\
\text { dan } \\
\text { data } \\
\text { sintesis } \\
\text { wajah } \\
\end{array}$ & 1 & 650000 & $\begin{array}{l}\text { AlexNet } \\
\text { dan } \\
\text { VGG-16 }\end{array}$ & 30 & $\begin{array}{l}77.6 \\
\text { dan } \\
85.9\end{array}$ & $\begin{array}{l}\text { Bias pada data memiliki } \\
\text { pengaruh terhadap } \\
\text { pengenalan wajah } \\
\text { menggunakan metode } \\
\text { DCNN. }\end{array}$ \\
\hline [17] & $\begin{array}{l}\text { SUN, } \\
\text { Caltech } \\
101 \text { and }\end{array}$ & 40 & N/A & DeCaf & N/A & N/A & $\begin{array}{l}\text { Menerapkan fitur DeCaf dan } \\
\text { BOWsift untuk } \\
\text { memverifikasi bias yang ada }\end{array}$ \\
\hline
\end{tabular}




\begin{tabular}{|c|c|c|c|c|c|c|c|}
\hline Makalah & Dataset & $\begin{array}{c}\text { Jumlah } \\
\text { Kelas }\end{array}$ & $\begin{array}{l}\text { Jumlah } \\
\text { gambar }\end{array}$ & $\begin{array}{c}\text { Algorit } \\
\text { ma }\end{array}$ & Epoch & $\mathbf{m A P}$ & Hasil/Keluaran \\
\hline & $\begin{array}{l}\text { Pascal } \\
\text { VOC07 }\end{array}$ & & & & & & $\begin{array}{l}\text { pada dataset dan mencoba } \\
\text { menyelesaikan masalah bias } \\
\text { yang ada. }\end{array}$ \\
\hline [18] & $\begin{array}{l}\text { Casia } \\
\text { WebFa } \\
\text { ce }\end{array}$ & N/A & 455594 & $\begin{array}{l}\text { FaceNet } \\
\text {-NN4, } \\
\text { CMU- } \\
\text { Multi- } \\
\text { PIE, } \\
\text { LFW, } \\
\text { dan IJB- } \\
\text { A }\end{array}$ & 200 & $\begin{array}{l}91.2 \\
94.1 \\
\text { dan } \\
86.8\end{array}$ & $\begin{array}{l}\text { Mengurangi bias pada } \\
\text { dataset dengan menciptakan } \\
\text { dataset sintesis untuk wajah. } \\
\text { Pengaruh negatif bias } \\
\text { berkurang hingga } 75 \% \text {. }\end{array}$ \\
\hline [19] & $\begin{array}{l}\text { Data } \\
\text { wajah }\end{array}$ & 4 & 57320 & $\begin{array}{l}\text { CNN, } \\
\text { DB- } \\
\text { VAE, } \\
\text { dan } \\
\text { CNN+S } \\
\text { VM }\end{array}$ & 20 & $\begin{array}{l}75.46 \\
89.56 \\
\text { dan } \\
83.70\end{array}$ & $\begin{array}{l}\text { Menerapkan pendekatan } \\
\text { domain-independent yang } \\
\text { bernama score-based } \\
\text { resampling (SBR). }\end{array}$ \\
\hline
\end{tabular}

\subsection{Analisis Dataset}

Pada tabel 1 telah didapatkan 21 dataset berbeda yang digunakan dalam pelatihan deteksi objek. Penelitian sebelumnya telah melakukan pembuatan dataset untuk berbagai macam keperluan yang berbeda. Berikut pada Tabel 2 didapatkan hasil analisis pada dataset yang telah dibuat oleh peneliti sebelumnya.

Tabel 2. Hasil Analisis Dataset

\begin{tabular}{|c|c|c|}
\hline Makalah & Teknik Pengumpulan Data & Teknik Anotasi \\
\hline [3] & $\begin{array}{l}\text { Data dikumpulkan melalui Flicker agar } \\
\text { memiliki variasi yang banyak. Kemudian, } \\
\text { dataset ini menghindari gambar yang hanya } \\
\text { berpusat pada satu objek atau disebut dengan } \\
\text { isitilah non-iconic images. Teknik tersebut } \\
\text { sudah diterapkan pada datset COCO. Sebelum } \\
\text { gambar yang ada pada dataset dianotasi, } \\
\text { gambar tersebut perlu melewati tahapan } \\
\text { berikut, yakni memilah gambar yang } \\
\text { memenuhi kriteria sebagai iconic images. }\end{array}$ & $\begin{array}{l}\text { Memberikan kategori, dan } \\
\text { melakukan anotasi sesuai dengan } \\
\text { kelasnya terhadap gambar yang } \\
\text { sudah terkumpul. Proses anotasi } \\
\text { menggunakan dua aturan utama, } \\
\text { yakni aturan klasifikasi dan } \\
\text { bounding box. Aturan klasifikasi } \\
\text { memiliki keterkaitan dengan } \\
\text { pemberian label untuk } \\
\text { menghindari ambiguitas dan } \\
\text { autran bounding box untuk } \\
\text { memberikan kesepakatan area } \\
\text { yang akan dianotasi pada setiap } \\
\text { kelas. }\end{array}$ \\
\hline [5] & $\begin{array}{l}\text { Dataset dikumpulkan untuk keperluan } \\
\text { mendeteksi pakaian atau benda yang dikenakan } \\
\text { oleh manusia. Data dikumpulkan dari }\end{array}$ & $\begin{array}{lcr}\text { Gambar } & \text { pada dataset } & \text { dianotasi } \\
\text { dengan } & \text { teknik } & \text { poligon. } \\
\text { Kemudian, } & \text { anotator } & \text { dapat } \\
\text { melewati } & \text { gambar } & \text { yang } \\
\end{array}$ \\
\hline
\end{tabular}




\begin{tabular}{|c|c|c|}
\hline Makalah & Teknik Pengumpulan Data & Teknik Anotasi \\
\hline & $\begin{array}{l}\text { PaperDoll dataset karena memiliki variasi yang } \\
\text { banyak dan relevan dengan kebutuhan deteksi } \\
\text { objek yang dibuat oleh peneliti sebelumnya. } \\
\text { Kemudian, secara manual dipilih sebanyak } \\
2000 \text { gambar yang memiliki kualitas rendah } \\
\text { dan } 2000 \text { gambar dengan kualitas tinggi. }\end{array}$ & $\begin{array}{l}\text { menurutnya ambigu untuk tidak } \\
\text { dianotasi. }\end{array}$ \\
\hline [7] & $\begin{array}{l}\text { Data yang digunakan merupakan gambar area } \\
\text { yang ditangkap dari udara. Gambar tersebut } \\
\text { dikumpulkan menggunakan beragam sensor } \\
\text { dan platform (contohnya Google Earth). Untuk } \\
\text { meningkatkan variasi data, peneliti juga } \\
\text { mengumpulkan data dari berbagai kota dalam } \\
\text { waktu yang berbeda-beda }\end{array}$ & $\begin{array}{l}\text { Metode anotasi yang digunakan } \\
\text { berupa }\left(x_{c}, y_{c}, w, h, \theta\right) \text {, dimana } \theta \\
\text { merupakan sudut dari bounding } \\
\text { box. Dengan menerapkan teknik } \\
\text { metode anotasi tersebut, anotator } \\
\text { dapat melakukan anotasi yang } \\
\text { baik terhadap objek yang } \\
\text { memiliki orientasi miring dan } \\
\text { mengurangi overlap yang } \\
\text { berlebih akibat dari bounding box } \\
\text { yang tidak dapat diatur sudutnya. }\end{array}$ \\
\hline$[10]$ & $\begin{array}{l}\text { Dataset dipergunakan untuk keperluan } \\
\text { mendeteksi plat nomor kendaraan yang } \\
\text { menggunakan angka iran. Data didapatkan dari } \\
\text { pengambilan gambar dengan kamera yang } \\
\text { tidak dikalibrasi. Variasi gambar didapatkan } \\
\text { dari perbedaan kondisi cahaya, perbedaan } \\
\text { resolusi, kontras, jarak, dan sudut pemotretan }\end{array}$ & $\begin{array}{l}\text { Proses anotasi data dilakukan } \\
\text { secara otomatis dengan validasi } \\
\text { bertahap. Aplikasi yang } \\
\text { digunakan adalah Ybat. }\end{array}$ \\
\hline [6] & $\begin{array}{l}\text { Dataset dikumpulkan dengan cara merekam } \\
\text { perjalanan yang dilalui dengan kondisi jalan } \\
\text { yang padat lalu lintas, sepi lalu lintas, serta } \\
\text { melewati jalan raya, dan jalan desa. Perekaman } \\
\text { dibantu dengan kamera yang disebut dengan } \\
\text { istilah event cameras. Kamera tersebut juga } \\
\text { menghasilkan pengukuran gambar gray-level } \\
\text { yang dapat digunakan dalam anotasi jika } \\
\text { diperlukan. Dataset tersebut juga mendukung } \\
\text { anotasi frekuensi rendah untuk meningkatkan } \\
\text { variasi objek dari berbagai aspek. }\end{array}$ & \multirow[t]{2}{*}{$\begin{array}{l}\text { Anotasi dilakukan dengan cara } \\
\text { pemberian bounding box } \\
\text { terhadap setiap objek yang ada } \\
\text { pada gambar dan memberikan } \\
\text { label sesuai dengan kelasnya. }\end{array}$} \\
\hline $\begin{array}{c}{[8],[12]} \\
{[13]}\end{array}$ & $\begin{array}{l}\text { Pengumpulan data dilakukan untuk mendeteksi } \\
\text { objek tertentu dan kelas yang digunakan tidak } \\
\text { begitu banyak. Dalam pengumpulannya } \\
\text { dilakukan secara manual dengan alat terbatas } \\
\text { berupa satu sumber sensor, yakni kamera } \\
\text { handphone. Gambar yang diambil } \\
\text { dikumpulkan secara manual dan didapatkan } \\
\text { langsung dari lapangan. Variasi yang ada pada } \\
\text { data tersebut bersumber dari lokasi } \\
\text { pengambilan foto yang berbeda-beda. } \\
\text { Meskipun pengambilan hanya bersumber dari } \\
\text { satu sensor dan beberapa tempat di lapangan, }\end{array}$ & \\
\hline
\end{tabular}




\begin{tabular}{|c|c|c|}
\hline Makalah & Teknik Pengumpulan Data & Teknik Anotasi \\
\hline & $\begin{array}{l}\text { akurasi yang dihasilkan cukup baik dengan } \\
\text { nilai mAP diatas } 70.00 \text {. Nilai tersebut } \\
\text { didapatkan karena gambar yang dikumpulkan } \\
\text { cukup mewakilkan pengujian yang dilakukan } \\
\text { di lapangan. }\end{array}$ & \\
\hline [9] & $\begin{array}{l}\text { Data dikumpulkan dari satu kamera yang } \\
\text { diletakkan pada sebuah tower. Kemudian, } \\
\text { dilakukan pemotongan gambar secara manual } \\
\text { untuk mendapatkan sebuah objek kapal. } \\
\text { Diperoleh sebanyak } 107 \text { kapal berbeda yang } \\
\text { menjadi kelas dengan total gambar sebanyak } \\
\text { 5523. Setelah itu, peneliti menggunakan Mask- } \\
\text { RCNN untuk mendeteksi kapal dengan tujuan } \\
\text { untuk mendapatkan gambar kapal dengan } \\
\text { resolusi yang baik. Kemudian, gambar yang } \\
\text { sudah diperoleh diperbesar menggunakan } \\
\text { Mask-RCNN sehingga didapat dataset awal } \\
\text { sekitar } 800 \text { gambar yang kemudian } \\
\text { ditingkatkan dengan teknik augmentasi dengan } \\
\text { library ImgAug. }\end{array}$ & \\
\hline [11] & $\begin{array}{l}\text { Dataset digunakan untuk keperluan mendeteksi } \\
\text { jalan yang rusak. Pengambilan gambar } \\
\text { menggunakan smartphone yang diletakkan } \\
\text { pada dashboard mobil. Pada makalah tersebut } \\
\text { dijelaskan bahwa pada umumnya dataset } \\
\text { jalanan rusak diambil secara tegak lurus } \\
\text { menghadap ke permukaan jalan. Hal tersebut } \\
\text { akan menyulitkan ketika praktik di lapangan. } \\
\text { Oleh karena itu, peneliti membuat dataset baru } \\
\text { dengan sudut pengambilan gambar dari } \\
\text { dashboard mobil yang akan memudahkan } \\
\text { banyak orang untuk praktik melalui kursi } \\
\text { depan penumpang tanpa harus turun dari } \\
\text { kendaraan. }\end{array}$ & \\
\hline
\end{tabular}

\subsection{Analisis Dataset Bias}

Tabel 3. Hasil Analisis Dataset Bias

\begin{tabular}{|c|l|l|l|}
\hline Makalah & $\begin{array}{l}\text { Sumber } \\
\text { Dataset }\end{array}$ & Identifikasi Bias pada Dataset & \multicolumn{1}{|c|}{$\begin{array}{c}\text { Teknik Mengatasi Bias } \\
\text { pada Dataset }\end{array}$} \\
\hline$[16],[18]$, & $\begin{array}{l}\text { Dataset } \\
\text { untuk } \\
\text { mendeteksi } \\
\text { wajah. }\end{array}$ & $\begin{array}{l}\text { Bias yang terjadi pada dataset } \\
\text { deteksi wajah berupa tidak } \\
\text { lengkapnya perubahan sudut } \\
\text { wajah dan arah datangnya } \\
\text { cahaya. }\end{array}$ & $\begin{array}{l}\text { Untuk mengurangi bias yang } \\
\text { terjadi, peneliti menggunakan } \\
\text { alat bantu yang bernama Face } \\
\text { Image Generator Alat } \\
\text { tersebut membantu peneliti } \\
\text { untuk membuat data sintesis } \\
\text { guna membantu melengkapi } \\
\text { perubahan sudut wajah dan } \\
\text { arah datangnya cahaya. }\end{array}$ \\
\hline
\end{tabular}




\begin{tabular}{|c|c|c|c|}
\hline Makalah & $\begin{array}{l}\text { Sumber } \\
\text { Dataset }\end{array}$ & Identifikasi Bias pada Dataset & $\begin{array}{c}\text { Teknik Mengatasi Bias } \\
\text { pada Dataset }\end{array}$ \\
\hline & & & $\begin{array}{l}\text { Secara signifikan, pada } \\
\text { penelitian tersebut bias yang } \\
\text { terjadi dapat berkurang dan } \\
\text { performa deteksi wajah } \\
\text { menjadi lebih baik. }\end{array}$ \\
\hline [19] & & $\begin{array}{l}\text { Bias yang terjadi dikarenakan } \\
\text { dalam satu dataset ada data yang } \\
\text { dominan. Contoh data tersebut, } \\
\text { yakni dalam satu kelas jika } \\
\text { terdapat satu wajah pria berkulit } \\
\text { terang yang jumlahnya lebih } \\
\text { dominan maka akan mengurangi } \\
\text { kemampuan deteksi untuk wajah } \\
\text { pria yang berkulit gelap. }\end{array}$ & $\begin{array}{l}\text { Membuat kelas baru yang } \\
\text { spesifik. Contohnya, wajah } \\
\text { pria dibuat menjadi dua kelas } \\
\text { untuk pria berkulit terang dan } \\
\text { berkulit gelap. }\end{array}$ \\
\hline [17] & $\begin{array}{l}\text { Caltech, } \\
\text { Pascal VOC, } \\
\text { SUN, ETH, } \\
\text { dan Bing. }\end{array}$ & $\begin{array}{l}\text { Bias yang ditemukan berupa bias } \\
\text { penangkapan dan label bias. Bias } \\
\text { penangkapan merupakan jenis } \\
\text { bias yang dipengaruhi oleh } \\
\text { pengambilan gambar secara } \\
\text { teknikal berupa pengaruh dari } \\
\text { sensor penangkapan gambar, } \\
\text { sudut pengambilan gambar, } \\
\text { perbedaan kondisi cahaya, dan } \\
\text { sejenisnya. Kemudian, label bias } \\
\text { merupakan bias yang terjadi } \\
\text { karena kesalahan pemberian } \\
\text { label, gambar yang sama bisa } \\
\text { diberikan label yang berbeda } \\
\text { atau gambar yang berbeda pun } \\
\text { bisa memiliki label yang sama } \\
\text { sehingga memungkinkan } \\
\text { terjadinya bias dalam satu set } \\
\text { kumpulan data. }\end{array}$ & $\begin{array}{l}\text { Menerapkan fitur DeCAF dan } \\
\text { BOWsift dalam mempelajari } \\
\text { bias yang ada dalam dataset. }\end{array}$ \\
\hline
\end{tabular}

\section{KESIMPULAN}

Berdasarkan hasil penelitian yang telah dilakukan, ditemukan 46 makalah dari kata kunci yang diberikan dan didapatkan 16 makalah yang memenuhi kriteria pencarian lalu dikelompokkan berdasarkan dataset, jumlah kelas, jumlah gambar, algoritma, epoch, mAP, dan hasil/keseluruhan dengan hasil yang beragam. Dalam pembuatan dataset yang baik dapat dilakukan dengan cara menyesuaikan kondisi pengambilan gambar saat pengumpulan data dan pengujian di lapangan. Selain itu, untuk dapat menambah kemampuan generalisasi sistem dengan cara menambahkan variasi gambar dalam dataset melalui teknik augmentasi. Selanjutnya, dalam proses pembuatan dataset pasti akan selalu ada bias dalam data sehingga mempengaruhi kemampuan deteksi objek. Oleh karena itu, dalam proses pembuatan sistem deteksi objek, data memiliki pengaruh yang cukup besar terhadap performa akurasi deteksi objek. Kemudian, pada jumlah kelas dan gambar yang digunakan cukup beragam, yaitu 2 sampai 365 kelas dan 600 sampai 638000 gambar, jumlah gambar yang banyak tidak selalu memberikan nilai mAP yang tinggi begitu juga sebaliknya. Adanya kajian dalam 
makalah ini dapat memberikan petunjuk yang baik bagi pengembang untuk dapat menciptakan dataset yang ideal sesuai dengan kebutuhan.

\section{DAFTAR PUSTAKA}

[1] R. A. Putro Eko Cahyo, Awangga Maulana Rolly, Tutorial Object Detection People With Faster region-Based Convolutional Neural Network(Faster R-CNN). Kreatif, 2020.

[2] E. C. Rahmad, S. T. M. Kom, D. Rawansyah, M. Pd, and T. K. Rochastu, "Mendeteksi Objek Sekitar untuk Penyandang," pp. 81-88, 2018.

[3] S. Shao et al., "Objects365: A large-scale, high-quality dataset for object detection," Proceedings of the IEEE International Conference on Computer Vision, vol. 2019-Octob, pp. 8429-8438, 2019, doi: 10.1109/ICCV.2019.00852.

[4] A. Khosla, T. Zhou, T. Malisiewicz, A. A. Efros, and A. Torralba, "Undoing the damage of dataset bias," Lecture Notes in Computer Science (including subseries Lecture Notes in Artificial Intelligence and Lecture Notes in Bioinformatics), vol. 7572 LNCS, no. PART 1, pp. 158-171, 2012, doi: 10.1007/978-3-642-33718-5_12.

[5] S. Zheng, M. Hadi Kiapour, F. Yang, and R. Piramuthu, "ModaNet: A large-scale street fashion dataset with polygon annotations," MM 2018 - Proceedings of the 2018 ACM Multimedia Conference, pp. 1670-1678, 2018, doi: 10.1145/3240508.3240652.

[6] P. de Tournemire, D. Nitti, E. Perot, D. Migliore, and A. Sironi, "A Large Scale Event-based Detection Dataset for Automotive," 2020, [Online]. Available: http://arxiv.org/abs/2001.08499.

[7] G. Xia et al., "DOTA: A Large-Scale Dataset for Object Detection in Aerial Images |Enhanced Reader," pp. 3974-3983, [Online]. Available: moz-extension://bd0c5e16-8147-45c5-ae8b8401aaca2c83/enhanced-

reader.html?openApp\&pdf=http\%3A\%2F\%2Fopenaccess.thecvf.com\%2Fcontent_cvpr_201 8\%2Fpapers\%2FXia_DOTA_A_Large-Scale_CVPR_2018_paper.pdf.

[8] A. Ziller, J. Hansjakob, V. Rusinov, D. Zügner, P. Vogel, and S. Günnemann, "Oktoberfest Food Dataset," pp. 1-4, 2019, [Online]. Available: http://arxiv.org/abs/1912.05007.

[9] P. Spagnolo, F. Filieri, C. Distante, P. L. Mazzeo, and P. D’Ambrosio, “A new annotated dataset for boat detection and re-identification," 2019 16th IEEE International Conference on Advanced Video and Signal Based Surveillance, AVSS 2019, no. September, 2019, doi: 10.1109/AVSS.2019.8909831.

[10] A. Tourani, S. Soroori, A. Shahbahrami, and A. Akoushideh, "Iranis: A Large-scale Dataset of Farsi License Plate Characters," 2021, [Online]. Available: http://arxiv.org/abs/2101.00295.

[11] H. Maeda, Y. Sekimoto, T. Seto, T. Kashiyama, and H. Omata, "Road Damage Detection Using Deep Neural Networks with Images Captured Through a Smartphone,” pp. 4-6, 2018, doi: $10.1111 /$ mice. 12387.

[12] P. S. Statistika, F. Matematika, D. A. N. Ilmu, P. Alam, and U. I. Indonesia, "IMPLEMENTASI DEEP LEARNING OBJECT DETECTION RAMBU K3 PADA VIDEO MENGGUNAKAN METODE CONVOLUTIONAL NEURAL NETWORK ( CNN ) DENGAN," 2020.

[13] A. Tri Nurolan, "Deteksi Dan Klasifikasi Jenis Kendaraan Berbasis Pengolahan Citra Dengan Metode Convolutional Neural Network (Cnn)," 2019. 
[14] R. Huang, J. Pedoeem, and C. Chen, "YOLO-LITE: A Real-Time Object Detection Algorithm Optimized for Non-GPU Computers," Proceedings - 2018 IEEE International Conference on Big Data, Big Data 2018, pp. 2503-2510, 2019, doi: 10.1109/BigData.2018.8621865.

[15] A. Gupta, A. Murali, D. Gandhi, and L. Pinto, "Robot learning in homes: Improving generalization and reducing dataset bias," Advances in Neural Information Processing Systems, vol. 2018-Decem, pp. 9094-9104, 2018.

[16] A. Kortylewski, B. Egger, A. Schneider, T. Gerig, A. Morel-Forster, and T. Vetter, "Empirically analyzing the effect of dataset biases on deep face recognition systems," IEEE Computer Society Conference on Computer Vision and Pattern Recognition Workshops, vol. 2018-June, pp. 2174-2183, 2018, doi: 10.1109/CVPRW.2018.00283.

[17] T. Tommasi, N. Patricia, B. Caputo, and T. Tuytelaars, "A deeper look at dataset bias," Advances in Computer Vision and Pattern Recognition, no. 9783319583464, pp. 37-55, 2017, doi: 10.1007/978-3-319-58347-1_2.

[18] A. Kortylewski et al., "Can Synthetic Faces Undo the Damage of Dataset Bias to Face Recognition and Facial Landmark Detection?," 2018, [Online]. Available: http://arxiv.org/abs/1811.08565.

[19] E. Derman, "Dataset Bias Mitigation Through Analysis of CNN Training Scores." 